\title{
Metode Pembelajaran Matematika di Sekolah Dasar Saat Pandemi Covid-19
}

\author{
Muhammad Nur Faisal', Tria Mardiana ${ }^{2}$, Muhammad Japar ${ }^{3}$ \\ 1,2,3Pendidikan Guru SD FKIP Universitas Muhammadiyah Magelang \\ email: muhammadnurfaisal1@gmail.com¹, triamardiana@ummgl.ac.id², \\ muhammadjapar69@gmail.com ${ }^{3}$
}

\begin{abstract}
This study aims to determine the learning methods used by teachers in Muhammadiyah Tempuran elementary school in Mathematics during online learning during the Covid-19 pandemic. This research was conducted in Muhammadiyah Tempuran Elementary School, Tempuran sub-district, Magelang regency. This research was conducted using data collection methods in the form of interviews conducted with school principals, teachers, students and parents, observations of teachers, students, and parents, and observation of several supporting documents. This research uses a qualitative approach with a qualitative descriptive type. The data validity test used triangulation technique. Triangulation used, source triangulation and technique triangulation. The data analysis technique used data analysis techniques from Miles and Huberman which consisted of 4 stages, namely, data collection, data reduction, data presentation, and drawing conclusions. The results of this study indicate that the learning methods used by teachers at SD Muhammadiyah Tempuran elementary school in mathematics during online learning during the Covid-19 pandemic, is assignments and materials. By use WhatsApp in providing assignments and collecting assignments from students, using google classroom, and google form, assignments in writing and via google form, forms of reporting student assignments, namely in the form of photos, videos sent via the Whatsapp group or email. The delivery of learning materials is carried out by lecturing and demonstration methods via video and utilizing YouTube, using PPT, photos, and documents sent via the Whatsapp group.
\end{abstract}

Keywords: Mathematics Learning Methods, Online Learning, Pandemic

Abstrak. Penelitian ini bertujuan untuk mengetahui metode pembelajaran yang digunakan oleh guru di SD Muhammadiyah Tempuran pada mata pelajaran Matematika selama pembelajaran daring di masa pandemi covid-19. Penelitian ini dilakukan di SD Muhammadiyah Tempuran, kecamatan Tempuran, Kabupaten Magelang. Penelitian ini dilakukan dengan menggunakan metode pengambilan data berupa wawancara yang dilakukan pada kepala sekolah, guru, siswa dan orang tua, observasi pada guru, siswa, dan orang tua, serta pencermatan beberapa dokumen pendukung.Penelitian ini menggunakan pendekatan kualitatif dengan jenis deskriptif kualitatif. Uji keabsahan data menggunakan teknik triangulasi. Triangulasi yang digunakan, triangulasi sumber dan triangulasi teknik. Teknik analisis data menggunakan teknik analisis data dari Miles dan Huberman yang terdiri dari 4 tahap yaitu, pengumpulan data, reduksi data, penyajian data, dan penarikan kesimpulan. Hasil dari penelitian ini menunjukkan bahwa metode pembelajaran yang digunakan oleh guru di SD Muhammadiyah 
Tempuran pada mata pelajaran matematika selama pembelajaran daring di masa pandemic covid-19, yaitu penugasan dan pemberian materi. Dengan memanfaatkan whatsapp dalam memberikan tugas dan pengumpulan tugas dari siswa, menggunakan google classroom, dan google form, penugasan secara tertulis dan melalui google form, bentuk pelaporan tugas dari siswa yaitu berupa foto, video yang dikirim melalui grup whatsapp atau email. Penyampain materi pembelajaran dilakukan dengan metode ceramah dan demonstrasi melalui video dan memanfaatkan youtube, menggunakan PPT, foto, dan dokumen yang di kirim melalui grup whatsapp.

Kata Kunci: Metode Pembelajaran Matematika, Pembelajaran Daring, Pandemi

\section{PENDAHULUAN}

Proses pendidikan mengalami perubahan karena adanya wabah covid-19. Covid-19 berdampak langsung pada aspek pendidikan, hingga pada tanggal 24 Maret 2020, Menteri Pendidikan dan Kebudayaan Republik Indonesia mengeluarkan surat edaran Nomor 4 Tahun 2020, mengenai Pelaksanaan Pendidikan Dalam Masa Darurat Coronavirus Disease (COVID 19) ada empat poin kebijakan terkait pembelajaran daring, pertama, pembelajaran daring/jarak jauh untuk memberi pengalaman belajar yang bermakna, tanpa terbebani tuntutan menuntaskan seluruh capaian kurikulum untuk kenaikan kelas maupun kelulusan. Kedua, dapat difokuskan pada pendidikan kecakapan hidup, antara lain mengenai pandemi Covid-19. Ketiga, aktivitas dan tugas pembelajaran dapat bervariasi antar siswa, sesuai minat dan kondisi masingmasing, termasuk mempertimbangkan kesenjangan akses/fasilitas belajar di rumah, dan bukti atau aktifitas belajar dirumah diberi umpan balik yang bersifat kualitatif dan berguna dari guru, tanpa diharuskan memberikan skor atau nilai kuantitatif.

Dampak dari adanya penyebaran virus tersebut kegiatan belajar mengajar di sekolah beralih ke pembelajaran secara daring. Meskipun bukanlah hal yang mudah untuk diterapkan. Pembelajaran secara daring membutuhkan penyesuaian dan adaptasi.

Terbatasnya interaksi antara guru dan siswa dan penggunaan media serta metode pembelajaran selama proses pembelajaran daring ditengarai mempengaruhi minat belajar siswa, selain itu alokasi waktu belajar pun menjadi berkurang . Pemilihan metode pembelajaran yang sesuai perlu dilakukan oleh guru, karena metode pembelajaran merupakan salah satu cara atau strategi yang dapat membantu guru dalam proses pembelajaran.

\begin{tabular}{lrrr}
\multicolumn{2}{c}{ Pembelajaran } & secara & daring \\
berdampak besar pada & pelajaran \\
matematika, & penggunaan & metode
\end{tabular} pembelajaran yang sesuai pada pelajaran matematika merupakan hal yang perlu diperhatikan oleh guru, agar proses pembelajaran daring dapat berjalan dengan baik. Berdasarkan permasalahan tersebut di atas, maka penelitian ini penting untuk dilakukan. 
Jurnal Riset Pendidikan Dasar

Volume 2 Nomor 2, September 2021; DOI 10.30595/jrpd.v2i2.9841

METODE

Penelitian ini menggunakan pendekatan penelitian kualitatif Moleong (2017:11). Penelitian ini dilaksanakan di SD Muhammadiyah Tempuran Puworejo Partisipan dalam penelitian ini adalah kepala sekolah, guru kelas, siswa dan orang tua siswa. Penelitian dilaksanakan pada semester gasal tahun 2020/2021 pada bulan Juni-Agustus 2020.

Teknik pengumpulan data yang digunakan pada penelitian ini yaitu wawancara, observasi, dan dokumentasi. Pada penelitian ini dokumen yang digunakan dalam pengumpulan data yaitu berupa RPP yang digunakan guru selama pembelajaran daring, daftar nilai, presensi siswa, pemberian materi dan tugas melalui whatsapp, google classroom, google form dan youtube.

Untuk menguji keabsahan data yang diperoleh sehingga benar-benar sesuai dengan tujuan dan maksud penelitian, maka peneliti menggunakan teknik triangulasi. Menurut Sugiyono (2017:269), Keabsahan data adalah derajat kepercayaan atas penelitian yang diperoleh dan dipertanggung jawabkan kebenarannya. Menurut Moleong (2017:330) triangulasi merupakan teknik keabsahan data yang memanfaatkan sesuatu yang lain diluar data itu untuk keperluan pengecekan atau sebagai pembanding terhadap data, dengan kata lain peneliti dapat merechek temuannya dengan jalan membandingkanya dengan berbagai sumber. Teknik triangulasi yang digunakan pada penelitian ini untuk menguji keabsahan data yaitu menggunakan teknik triangulasi sumber dan triangulasi teknik.

Analisis data merupakan cara yang dilakukan untuk menganalisa hasil dari data yang diperoleh dalam penelitian sehingga lebih mudah dibaca dan diinterpretasikan Sugiyono (2017:244). Analisis data yang peneliti lakukan yaitu menggunakan teknik analisis data dari Miles and Huberma. Terdiri dari empat tahap yaitu pengumpulan data, reduksi data, penyajian data, dan penarikan kesimpulan (Herdiansyah, 2010:164).

\section{HASIL}

Hasil penelitian ini berpedoman pada data yang berasal dari hasil wawancara, observasi, dan dokumentasi. Aspek yang menjadi kajian dalam penelitian ini metode pembelajaran yang diterapkan oleh guru pada mata pelajaran matematika selama pembelajaran daring di SD Muhammadiyah Tempuran. Analisis data yang digunakan pada penelitian ini menggunakan teori dari Miles and Huberman yang terdiri dari beberapa tahap yaitu pengumpulan data, reduksi data, penyajian data, dan penarikan kesimpulan. Penelitian ini menggunakan interpretasi data secara deskriptif berupa uraian kalimat sebagai berikut.

1. Hasil wawancara penggunaan metode pembelajaran pada mata pelajaran matematika selama pembelajaran daring terhadap kepala sekolah.

Hasil wawancara yang dilakukan pada kepala sekolah, kegiatan pembelajaran selama pandemi covid-19 di SD Muhammadiyah Tempuran dilakukan secara daring karena tidak memungkinkan pembelajaran secara langsung hal tersebut sesuai dengan surat edaran dari menteri pendidikan terkait proses pembelajaran pada masa pandemi. 
Menurut wawancara yang dilakukan pada kepala sekolah guru tetap diwajibkan untuk membuat RPP dan perangkat pembelajaran lainnya seperti silabus, prota, promes, dan setiap hari sabtu selalu diadakan kegiatan evaluasi terkait proses pembelajaran secara daring dan guru selalu diminta untuk mengumpulkan RPP dan perangkat pembelajaran lainnya. Kebijakan yang dilakukan oleh kepala sekolah agar proses pembelajaran selama pandemi tetap dapat berjalan yaitu guru diminta untuk membuat video pembelajaran, materi pembelajaran, yang kemudian di bagikan melalui grup whatsapp wali murid setiap kelas, selain itu kepala sekolah juga memberikan arahan pada guru untuk melakukan berbagai inovasi pembelajaran dengan memanfaatkan beberapa aplikasi seperti goggle classroom, google form. Menurut hasil wawancara pada kepala sekolah semua siswa memiliki sarana dan prasarana untuk mengikuti pembelajaran secara daring.

Menurut hasil wawancara pada kepala sekolah penanaman karakter yang harus diberikan oleh guru pada siswa yaitu meliputi mewajibkan siswa untuk melakukan sholat dhuha, sholat fardu, dan hafalan. Selain itu penanaman karakter yang harus diberikan yaitu dengan membantu orang tua, setiap kegiatan yang dilakukan oleh siswa harus dilaporkan pada guru melalui foto atau video kemudian dikirim melalui whatsapp.

2. Hasil wawancara penggunaan metode pembelajaran pada mata pelajaran matematika selama pembelajaran daring terhadap guru
Hasil wawancara yang dilakukan pada guru mendapatkan kesaksian bahwa, untuk mengoptimalkan proses pembelajaran daring guru telah menerapkan berbagai metode pembelajaran untuk mendukung proses pembelajaran secara daring selama masa pandemi. Penerapan metode pembelajaran yang digunakan oleh guru yaitu dengan memanfaatkan jaringan internet atau online. Metode daring yang digunakan oleh guru selama pandemi covid-19 yaitu berupa penugasan dan penyampaian materi, untuk mendukung proses pembelajaran daring guru memanfaatkan berbagai macam aplikasi seperti whatsapp untuk melakukan komunikasi dengan siswa dan orang tua, mengirim materi pembelajaran, pemberian tugas dan pengumpulan tugas yang diberikan. Menurut hasil wawancara pada guru selain memanfaatkan whatsapp guru juga menggunakan google form untuk pemberian tugas, pemberian tugas melalui google form biasanya berbentuk soal pilihan ganda dan uraian singkat. Selama pembelajaran daring jenis penugasan yang diberikan pada siswa berbentuk tugas tertulis dan penugasan melalui google form, bentuk pelaporan tugas yang harus dikumpulan siswa yaitu berupa foto, video yang dikirim melalui grup whatsapp atau email dan mengisi google form yang sudah diberikan.

Berdasarkan wawancara yang dilakukan pada guru proses pembelajaran secara daring tidak lepas dari peran orang tua, orang tua berperan penting untuk membantu dan mengawasi siswa ketika belajar dirumah. 
Sedangkan untuk membatasi bantuan orang tua dalam penyelesaian tugas yang diberikan, yaitu dengan cara guru melakukan komunikasi dengan orang tua dan memberikan saran agar tidak menyelesaikan tugas dari guru dan orang tua dihimbau hanya mendampingi dan membimbing siswa jika mengalami kesulitan dalam menyelesaikan tugas. Menurut hasil wawancara pada guru selama pembelajaran daring dengan menggunakan berbagai metode dan aplikasi dalam proses pembelajaran nilai yang didapat siswa hampir semua di atas KKM dan jarang sekali siswa mendapat nilai di bawah rata-rata karena menurut guru selama belajar dirumah tidak lepas dari peran dan bantuan dari orang tua.

3. Hasil wawancara penggunaan metode pembelajaran pada mata pelajaran matematika selama pembelajaran daring terhadap orang tua

Berdasarkan hasil wawancara yang dilakukan pada orang tua siswa tentang metode pembelajaran yang dilakukan guru yaitu menghasilkan infomasi bahwa selama pembelajaran daring guru menggunakan metode penugasan dan pemberian materi pembelajaran. Penugasan diberikan melalui beberapa aplikasi seperti whatsapp, google formulis, google classroom. Penugasan yang diberikan guru pada siswa biasanya berbentuk tugas tertulis, mengerjakan tugas melalui google form dan google classroom, sedangkan dalam menyampaikan materi biasanya guru mengirim materi pembelajaran melalui whatsapp dalam bentuk PPT, pesan suara dan guru juga menggunakan video melalui youtube untuk menyampaikan materi pembelajaran.

Berdasakan hasil wawancara yang dilakukan pada orang tua, selama proses belajar dirumah orang tua selalu mendampingi anak ketika mengikuti pembelajaran, pendampingan yang dilakukan oleh orang tua berupa membimbing dan mengawasi siswa ketika belajar. Berdasarkan wawancara yang dilakukan pada orang tua siswa, pembelajaran melalui daring menurut orang tua kurang efektif dan kurang maksimal dibandingkan dengan tatap muka langsung, karena terbatasnya tatap muka secara langsung, dan penyampaian materi tidak bisa dilakukan secaran langsung, jika siswa kurang paham dengan materi yang disampaikan kesempatan untuk bertanya sangat terbatas. Selain itu orang tua juga harus bekerja lebih ekstra ketika mendampingi siswa belajar, karena jika siswa kurang paham dengan materi atau penugasan dari guru orang tua harus bias menjelaskannya.

4. Hasil wawancara penggunaan metode pembelajaran pada mata pelajaran matematika selama pembelajaran daring terhadap siswa

Menurut hasil wawancara yang dilakukan pada siswa, didapatkan informasi bahwa siswa melakukan kegiatan belajar dirumah selama masa pandemi dengan didampingi oleh orang tua. Berdasarkan hasil wawancara, metode pembelajaran yang digunakan guru yaitu dengam pemberian tugas dan memberikan materi pembelajar pada siswa. Pemberian tugas dari guru melaui whatsapp, google form dan google classroom. Sedangkan dalam 
menyampaikan materi guru menjelaskan dengan melalui video dan menggunakan youtube, selain menggunakan video guru juga memberikan materi melalui whatsapp dalam bentuk PPT, materi tertulis dan terkadang guru juga menyampaikan materi melalui pesan suara.

Menurut siswa belajar dirumah melalui daring lebih sulit dibandingkan belajar secara tatap muka langsung dengan guru, dan berdasarkan hasil wawancara dengan siswa dari kelas satu sampai enam rata-rata siswa lebih memilih pembelajaran secara langsung, karena menurut siswa belajar secara daring kurang maksimal, tidak bisa bertemu dengan guru dan terbatasnya interaski antara siswa dengan guru maupun siswa dengan siswa lainnya. Selain itu jika kurang jelas dan paham dengan materi yang disampaikan guru kesempatan bertanya pun sangat terbatas. Selain itu berdasarkan hasil wawancara pada siswa, siswa lebih memilih belajar secara tatap muka langsung dengan guru dibandingkan belajar dirumah secara daring. Selama belajar dirumah siswa didampingi dan dibantu oleh orang tua dalam mengerjakan tugas dari guru.

5. Hasil observasi mengenai penggunaan metode pembelajaran pada mata pelajaran matematika selama pembelajaran daring terhadap guru

Hasil obervasi yang dilakukan pada guru, sebelum menentukan metode pembelajaran yang akan digunakan selama pembelajaran daring guru melakukan pertimbang terlebih dahulu, pertimbangan yang dilakukan guru seperti kesesuaian metode dengan materi, tingkat kesulitan, kondisi siswa, ketepatan sasaran agar metode yang digunakan dapat membantu selama pembelajaran daring. Sebelum melakukan kegiatan belajar daring, Guru juga melakukan beberapa persiapan, persiapan yang dilakukan oleh guru yaitu mempersiapkan atau membuat RPP, membuat materi pembelajaran berupa video, ppt, materi tertulis, mencari referensi, membuat soal-soal. Berdasarkan hasil observasi, guru selalu mengecek kesiapan siswa sebelum mengikuti pembelajaran daring dengan melakukan absensi melalui google form atau whatsapp.

6. Hasil observasi mengenai penggunaan metode pembelajaran pada mata pelajaran matematika selama pembelajaran daring terhadap orang tua

Berdasarkan hasil observasi terhadap orang tua siswa, selama proses belajar dirumah melalui daring orang tua selalu mendampingi siswa selama belajar, pendampingan belajar yang dilakukan oleh orang tua yaitu dengan melakukan pengawasan ketika siswa belajar menggunakan Handphone, karena menurut orang tua jika tidak diawasi ketika menggunakan handphone terkadang anak malah bermain dan kurang fokus saat mengerjakan soal maupun memahami materi dari guru. Selain melakukan pengaswasan orang tua juga mendampingi ketika belajar, karena jika anak kurang paham dengan materi atau tugas dari guru maka orang tua yang menjelaskannya pada siswa. Selain mendampingi dan mengawasi siswa selama belajar, orang tua juga menyiapkan atau menyediakan sarana 
prasana untuk mengikuti pembelajaran daring, sarana yang disiapkan yaitu handphone, jaringan internet (quota data), selain itu juga membantu dalam mempersiapkan buku, alat tulis, dan sumber belajar lainnya.

7. Hasil observasi mengenai penggunaan metode pembelajaran pada mata pelajaran matematika selama pembelajaran daring terhadap siswa.

Berdasarkan hasil observasi pada siswa, diperoleh data bahwa siswa mengikuti kegiatan belajar secara daring dengan memprsiapkan alat belajar berupa buku dan alat tulis, handphone atau laptop, buku paket dan sumber belajar lainnya. Menurut hasil observasi pada siswa menyatakan bahwa siswa melakukan aktifitas belajar menggunakan metode pembelajaran penugasan, terlihat dari kegiatan yang dilakukan oleh siswa yaitu mengerjakan tugas yang telah diberikan oleh guru melalui whatsapp maupun goggle form. Selain itu siswa juga menerima materi yang diberikan oleh guru melalui whatsapp dan melihat video pembelajaran melalui youtube yang telah diberikan oleh guru. Pengumpulan tugas yang telah diselesaikan oleh siswa dikumpulkan pada guru dengan bantuan orang tua, bentuk tugas yang dikumpulkan yaitu berbentuk foto, video, file, dan link google form tugas dikumpulkan melalui whatsapp atau email.

8. Hasil dokumentasi perangkat pembelajaran guru

Berdasarkan hasil dokumentasi terhadap perangkat pembelajaran guru, selama pembelajaran daring guru tetap membuat RPP dan perangkat pembelajaran yang digunakan selama proses pembelajaran daring, terbukti dari dokumen RPP yang telah dibuat oleh guru (terdapat pada lampiran). Selama proses pembelajaran secara daring guru juga membuat materi dan soal-soal yang kemudian dikirim melalui grup whatsap, materi yang dikirim oleh guru dalam bentuk foto, dokumen, pesan suara dan video.

Selama kegiatan pembelajaran secara daring siswa selalu mengikuti proses pembelajaran terbukti dari rekapan terdahadap presensi siswa. Presensi biasanya dilakukan melakukan google form dan whatsap. Nilai yang diperoleh siswa hampir semuanya di atas rata-rata dan sangat jarang siswa memperoleh nilai dibawah rata-rata, hal itu terbukti dari hasil dokumentasi terhadap rekapan dan daftar nilai siswa selama mengikuti pembelajaran daring. Berdasarkan hasil dokumentasi, didapatkan informasi berupa pengumpulan tugas yang dilakukan oleh orang tua, tugas yang dikumpulkan dalam bentuk foto, video, dokumen, link google form, tugas dikirim melalui whatsapp atau email.

\section{DISKUSI}

1. Hasil wawancara penggunaan metode pembelajaran pada mata pelajaran matematika selama pembelajaran daring terhadap kepala sekolah

Kepala sekolah telah melakukan tugasnya dengan baik, yaitu dengan tetap melakukan pengawasan terkait pelaksanaan pembelajaran secara daring yang dilakukan guru selama masa pandemic covid-19. Menurut Purwanto dalam Sulastri (2019:10), supervisi adalah segala bantuan dari para pimpinan sekolah, yang tertuju pada 
perkembangan kepemimpinan guruguru dan personal sekolah lainnya dalam mencapai tujuan pendidikan. Adanya pengawasan yang dilakukan oleh kepala sekolah, menjadikan guru tetap disiplin dalam melakukan pembelajaran selama masa pandemi covid-19.

Selain melakukan pengawasan terhadap pelaksanaan pembelajaran, kepala sekolah juga memberikan masukan semangat pada guru yang bertujuan agar guru selalu semangat dalam melaksanakan tugasnya meskipun terkendala oleh pandemi covid- 19. Hal tersebut membuktikan bahwa kepala sekolah bertanggung jawab atas tugasnya. Menurut Mujtahid (2011:65) Setiap perilaku kepala sekolah sebagai pemimpin pendidikan diarahkan untuk membantu pencapaian tujuan pendidikan, sehingga kepala sekolah berkewajiban dalam membina, mengarahkan, menugasi, memeriksa, mengukur hasil kerja para guru di sekolah yang dipimpinnya. Kebijakan yang dilakukan oleh kepala sekolah selama pandemi covid-19 yaitu dengan menerapkan pembelajaran secara dengan memberikan arahan pada guru dalam melaksanakan pembelajaran daring guru diarahkan untuk memanfaatkan jaringan internet,dan dengan memanfaatkan beberapa aplikasi seperti whatsapp, google form, google classroom, dan youtube.

2. Hasil wawancara penggunaan metode pembelajaran pada mata pelajaran matematika selama pembelajaran daring terhadap guru

Guru melakukan kegiatan pembelajaran dengan baik meskipun dalam kondisi pandemic covid-19, pembelajaran dilakukan secara daring dengan menggunakan beberapa aplikasi online seperti whatsapp, goole form, goole classroom, youtube untuk memudahkan dalam menyampaikan materi pembelajaran. Pada

penelitian Wahyu Aji (2020:58), Belajar daring (online) dapat menggunakan teknologi digital seperti google classroom, rumah belajar, zoom, video converence, telepon atau live chat dan lainnya.

Metode pembelajaran yang digunakan oleh guru selama pembelajaran daring yaitu berupa penugasan dan pemberian materi, metode pembelajaran yang digunakan oleh guru selama pembelajaran daring yaitu berupa penugasan dan pemberian materi. Menurut Arizona (2020:66), Pembelajaran online yang diterapkan dengan menggunakan media goggle calssroom memungkinkan pengajar dan peserta didik dapat melangsungkan pembelajaran tanpa melalui tatap muka di kelas dengan pemberian materi pembelajaran (berupa slide power point, ebook, video pembelajaran, tugas (mandiri atau kelompok), sekaligus penilaian.

Guru selalu memberikan umpan balik pada siswa setelah mengumpulkan tugas yang diberikan, umpan balik berupa memberikan nilai, mengirim kembali jawaban yang tepat dan memberikan apresiasi atau pujian pada siswa melalui whatsapp karena sudah menyelesaikan tugas yang diberikan guru. Menurut Windarsih (2016:23), umpan balik merupakan sebuah cara yang dilakukan oleh pendidik untuk membantu peserta didik dalam memahami suatu pembelajaran dengan 
Jurnal Riset Pendidikan Dasar

Volume 2 Nomor 2, September 2021; DOI 10.30595/jrpd.v2i2.9841

cara menanggapi hasil suatu pembelajaran yang dilakukan sampai peserta didik menguasai materi yang telah disampaikan. Penerapan berbagai metode pembelajaran yang dilakukan guru walaupun belum efektif dalam segi penyampaian materi, tetapi dinilai sudah efektif dari segi ketercapaian nilai pelajaran.

Kendala yang dialami guru ketika penerapan pembelajaran daring, kebanyakan terkait kendala waktu, sinyal dan quota internet. Selain itu kegiatan pembelajaran kurang interaktif karena kurangnya komunikasi secara langsung dengan siswa sehingga dalam penyampaian materi kurang maksimal. Guru juga dituntut lebih kretif dalam pelaksanaan pembelajaran daring agar kegiatan pembelajaran tidak membosankan dan dapat mengembalikan semangat siswa selama belajar dirumah.

3. Hasil wawancara penggunaan metode pembelajaran pada mata pelajaran matematika selama pembelajaran daring terhadap orang tua

Peran orang tua sangat penting dalam pembelajaran secara daring selama pandemi covid-19. Peran dari orang tua selama proses pembelajaran daring yaitu dengan mendampingi siswa ketika mengikuti pembelajaran, pendampingan yang dilakukan oleh orang tua berupa membimbing dan mengawasi siswa ketika belajar. Menurut hasil penelitian yang dilakukan oleh Putria dkk, menyatakan bahwa orang tua menjadi seseorang yang sangat penting dalam pelaksanaan pembelajaran daring, karena orang tua yang secara langsung terlibat dalam membimbing dan mengawasi peserta didik dalam pembelajaran. Pemberian motivasi menjadi sangat berarti bagi peserta didik, hal tersebut dilakukan agar peserta didik kembali semangat meskipun belajar dari rumah (Putria, 2020:871).

4. Hasil wawancara penggunaan metode pembelajaran pada mata pelajaran matematika selama pembelajaran daring terhadap siswa

Penerapan pembelajaran secara daring di sekolah dasar selama pandemi covid-19 memang dirasa kurang maksimal. Penggunaan beberapa aplikasi yang digunakan guru dalam proses pembelajaran daring, seperti whatsapp, google form, google classroom, dan youtube dapat membantu dan memudahkan siswa dalam mengikuti pembelajaran meskipun kegiatan pembelajaran tidak semaksimal ketika tatap muka secara langsung.

Pembelajaran daring menurut siswa membosankan dan berbeda dengan pembelajaran di sekolah, karena terbatasnya interaksi antara siswa dengan guru, maupun siswa dengan siswa lainnya. Menurut Purwanto (2020: 6) dampak lain dari pandemi Covid-19 terhadap peserta didik yaitu sekolah diliburkan terlalu lama membuat anakanak jenuh, anak-anak mulai jenuh di rumah dan ingin segera ke sekolah bermain dengan teman-temannya, peserta didik terbiasa berada di sekolah untuk berinteraksi dengan temantemannya, bermain dan bercanda gurau dengan teman-temannya serta bertatap muka dengan para gurunya.

5. Hasil observasi mengenai penggunaan metode pembelajaran pada mata 
pelajaran matematika selama pembelajaran daring terhadap guru.

Sebelum menentukan metode pembelajaran yang akan digunakan selama pembelajaran daring guru melakukan pertimbang terlebih dahulu, pertimbangan yang dilakukan guru seperti kesesuaian metode dengan materi, tingkat kesulitan, kondisi siswa, ketepatan sasaran agar metode yang digunakan dapat membantu selama pembelajaran daring. Guru juga melakukan beberapa persiapan, persiapan yang dilakukan oleh guru yaitu mempersiapkan atau membuat RPP, membuat materi pembelajaran berupa video, ppt, materi tertulis, mencari referensi, membuat soal-soal. Menurut Bararah (2017:132), RPP adalah rancangan pembelajaran mata pelajaran per unit yang memuat prosedur kegiatan belajar dari awal hingga yang sesuai dengan indikator dan tujuan pembelajaran yang telah dirumuskan, hal tersebut bertujuan agar kegiatan belajar mengajar menjadi lebih mudah dan lancar serta dapat meningkatkan hasil proses belajar mengajar.

\section{Sebelum}

pelaksanaan pembelajaran guru selalu mengecek kesiapan siswa sebelum mengikuti pembelajaran daring dengan melakukan absensi melalui google form atau whatsapp. Setiap hari sabtu guru melakukan kegiatan evaluasi, evaluasi yang dilakukan guru yaitu memberikan latihan soal, memberikan pembahasan terkait soal yang sudah diberikan, selain itu guru juga melakukan video call dengan siswa untuk menanyakan kabar dan perkembangan siswa selama belajar dirumah.
6. Hasil observasi mengenai penggunaan metode pembelajaran pada mata pelajaran matematika selama pembelajaran daring terhadap orang tua Selama proses belajar dirumah melalui daring orang tua selalu mendampingi siswa selama belajar, Pendampingan belajar yang dilakukan oleh orang tua yaitu dengan melakukan pengawasan ketika siswa belajar menggunakan handphone, karena menurut orang tua jika tidak diawasi ketika menggunakan handphone terkadang anak malah bermain dan kurang fokus saat mengerjakan soal maupun memahami materi dari guru. Selain melakukan pengaswasan orang tua juga mendampingi ketika belajar, karena jika anak kurang paham dengan materi atau tugas dari guru maka orang tua yang menjelaskannya pada siswa.

Kendala yang paling sering dihadapi oleh orang tua selama mendampingi siswa belajar secara daring yaitu pada jaringan internet. Menurut orang tua selama pembelajaran daring quota internet sangat boros, tebatasnya tatap muka secara langsung sehingga jika kurang jelas dengan materi dan penugasan komunikasinya terbatas, orang tua harus bekerja lebih ekstra dan harus ikut belajar karena jika siswa kurang jelas maka orang tua yang harus memberikan penjelasan pada siswa. Menurut Purwanto, dkk dalam penelitiannya menyatakan bahwa Kendala yang dihadapi para orang tua adalah adanya penambahan biaya pembelian kuota internet bertambah, teknologi online memerlukan koneksi jaringan ke internet dan kuota oleh karena itu tingkat penggunaaan kuota 
Jurnal Riset Pendidikan Dasar

Volume 2 Nomor 2, September 2021; DOI 10.30595/jrpd.v2i2.9841

internet akan bertambah dan akan menambah beban pengeluaran orang tua (Purwanto, 2020:8).

7. Hasil observasi mengenai penggunaan metode pembelajaran pada mata pelajaran matematika selama pembelajaran daring terhadap siswa

Berdasarkan hasil observasi siswa mengikuti kegiatan belajar secara daring dengan memprsiapkan alat belajar berupa buku dan alat tulis, jaringan internet/ kuota, handphone atau laptop, buku paket dan sumber belajar lainnya. Menurut Purwanto (2020:5), Fasilitas ini sangat penting untuk kelancaran proses belajar mengajar, untuk pembelajaran online di rumahnya seharusnya disediakan dulu fasilitasnya seperti laptop, komputer ataupun handphone yang akan memudahkan murid untuk menyimak proses belajar mengajar online.

Pengumpulan tugas yang telah diselesaikan oleh siswa dikumpulkan pada guru dengan bantuan orang tua, bentuk tugas yang dikumpulkan yaitu berbentuk foto, video, file, dan link google form tugas dikumpulkan melalui whatsapp atau email. Selain itu siswa juga menerima materi dari guru melalui whatsapp dan melihat video pembelajaran melalui youtube yang telah diberikan oleh guru.

8. Hasil dokumentasi perangkat pembelajaran guru

Selama proses pembelajaran secara daring guru tetap membuat RPP dan perangkat pembelajaran lainnya yang digunakan selama pembelajaran daring terbukti dari hasil dokumentasi pada perangkat pembelajaran guru. Melalui perencanaan yang baik, guru akan lebih mudah dalam melaksanakan pembelajaran dan siswa akan lebih terbantu dan mudah dalam belajar, dengan adanya perencanaan yang baik, maka pelaksanaan pembelajaran akan dapat berjalan lancar, terarah, dan sistematis. Hal ini dapat tercapai karena kompetensi dasar, materi pokok, indikator, pengalaman belajar, alokasi waktu, sumber langkah-langkah pembelajaran, dan rencana penilaian telah dirumuskan dengan baik dan digambarkan dengan jelas (Wahyuni dan Ibrahim, 2012:11-12).

Guru juga membuat materi dan soal-soal yang kemudian dikirim melalui grup whatsap, materi yang dikirim oleh guru dalam bentuk foto, dokumen, pesan suara dan video, dari hasil dokumentasi guru juga menggunakan aplikasi youtube ketika memberikan materi dengan cara mengirim link youtube melalui grup whatsapp. Kegiatan pembelajaran secara daring dilakukan menggunakan google form dan google classroom dalam pemberian tugas dan pengerjaan tugas oleh siswa. Dari hasil dokumentasi, didapatkan informasi berupa pengumpulan tugas yang dilakukan oleh orang tua, tugas yang dikumpulkan dalam bentuk foto, video, dokumen, link google form, tugas dikirim melalui whatsapp atau email.

\section{SIMPULAN}

Berdasarkan hasil penelitian dan pembahasan yang telah diuraikan, maka dapat disimpulkan bahwa:

Pandemi covid-19 berdampak langsung pada dunia pendidikan, terutama dalam proses pembelajaran yang dilaksanakan guru berubah secara drastis yang biasanya dilakukan secara tatap muka 
Jurnal Riset Pendidikan Dasar

Volume 2 Nomor 2, September 2021; DOI 10.30595/jrpd.v2i2.9841

langsung menjadi pembelajaran dalam jaringan (daring).

$\begin{array}{ccc}\text { Kepala } & \text { sekolah melakukan } \\ \text { pengawasan } & \text { terkait } & \text { pelaksanaan }\end{array}$

pembelajaran secara daring yang dilakukan guru selama masa pandemi covid-19. Kebijakan yang dilakukan kepala sekolah terkait pembelajaran secara daring, yaitu melalui memberi semangat pada guru untuk membuat metode dan media pembelajaran yang mudah dipahami dan dipelajari oleh siswa meskipun proses pembelajaran tidak dilakukan secara langsung dan hanya didampingi oleh orang tua dan memberikan arahan pada guru dengan membuat video pembelajaran dan menggunakan beberapa aplikasi seperti whatsapp, google form, youtube untuk menunjang proses pembelajaran secara daring.

Pembelajaran dilakukan secara daring dengan menggunakan beberapa aplikasi online seperti whatsapp, goole form, goole classroom, youtube untuk memudahkan dalam menyampaikan materi pembelajaran. Metode pembelajaran yang digunakan oleh guru selama pembelajaran daring yaitu berupa penugasan dan pemberian materi. Persiapan yang dilakukan oleh guru yaitu mempersiapkan atau membuat RPP, membuat materi pembelajaran berupa video, ppt, materi tertulis, mencari referensi, membuat soalsoal. Setiap hari sabtu guru melakukan kegiatan evaluasi, kegiatan evaluasi yang dilakukan guru yaitu memberikan latihan soal, memberikan pembahasan terkait soal yang sudah diberikan.

Kendala yang dialami guru ketika penerapan pembelajaran daring, kebanyakan terkait kendala waktu, sinyal dan quota internet. Selain itu kegiatan pembelajaran kurang interaktif karena kurangnya komunikasi secara langsung dengan siswa sehingga dalam penyampaian materi kurang maksimal. Guru juga dituntut lebih kreatif dalam pelaksanaan pembelajaran daring.

Orang tua berperan sangat penting dalam pembelajaran secara daring selama pandemi covid-19. Peran dari orang tua selama proses pembelajaran daring yaitu dengan mendampingi siswa ketika mengikuti pembelajaran, membimbing dan mengawasi siswa ketika belajar. Orang tua juga menyediakan sarana prasarana yang dapat digunakan siswa untuk mengikuti proses pembelajaran daring. Sarana prasarana yang disediakan oran tua seperti handphone, laptop, koneksi internet.

Siswa merasa bosan selama pembelajaran secara daring karena terbatasnya interaksi antara siswa dengan guru, maupun siswa dengan siswa lainnya. Selaian itu menurut siswa, belajara secara daring hanya berfokus pada handphone saja mulai dari mengerjakan tugas, mengumpulkan tugas, dan memahami materi yang disampaikan oleh guru.

\section{DAFTAR PUSTAKA}

Arizona, Kurniawan. (2020). Pembelajaran Online Berbasis Proyek Salah satu Solusi Kegiatan Belajar Mengajar Di Tengah Pandemi Covid-19. Jurnal Ilmiah Profesi Pendidikan. Vol 5 (1)

Bararah. (2017). Efektifitas Perencanaan Pembelajaran Pendidikan Agama islam di Sekolah. Jurnal Muddarrisuna, 7(1):131-147

Dewi, Wahyu Aji. (2020). Dampak Covid-19 Terhadap Implementasi Pembelajaran Daring Disekolah Dasar. Jurnal Ilmu Pendidikan , 2 (1):56. 
Jurnal Riset Pendidikan Dasar

Volume 2 Nomor 2, September 2021; DOI 10.30595/jrpd.v2i2.9841

Hilna Putria. Dkk. (2020). Analisis Proses Pembelajaran dalam Jaringan (DARING) Masa Pandemi Covid-19 Pada Guru Sekolah Dasar. Jurnal Basicedu, 4 (4):871

Moelong. (2017). Metodologi Penelitian Kualitatif. Bandung: PT Remaja Rosda Karya.

Mujtahid. (2011). Pengembangan Profesi Guru. Malang: UIN MALIKI Press.

Purwanto, Ngalim. (2012). Administrasi dan Supervisi Pendidikan. Yogyakarta: Gava Media

Purwanto, Agus, Pramono, Asbari, Santoso. (2020). "Studi Eksploratif Dampak Pandemi Covid-19 Terhadap Proses Pembelajaran Online di Sekolah Dasar". EduPsyCouns Journal, 2 (1), 5-7.

Sugiyono. (2017). Metode Penelitian Kuantitatif, Kualitatif, dan RED. Bandung: Alfabeta.

Wahyuni, Sri, Ibrahim. (2012). Perencanaan Pembelajaran Bahasa Berkarakter. Malang: Refika Aditama

Windarsih, Chandra Asri. (2016). Aplikasi Teori Umpan Balik (FEEDBACK) dalam Pembelajaran Motorik Pada Anak usia Dini. STKIP SILIWANGI Journals, 2 (1); 20-29. 